\title{
INTERJÚ
}

\section{Hornyik Zsuzsanna}

\section{Legyen a tudomány az iránytü mindenki számára!}

\author{
Interjú Freund Tamással, \\ a Magyar Tudományos Akadémia elnökével
}

\author{
Science should serve as a compass for everyone \\ Interview with Tamás Freund, president \\ of the Hungarian Academy of Sciences
}

\begin{abstract}
Absztrakt
A Magyar Tudományos Akadémia (MTA) 2020. július 7-én tartott 193. tisztújító közgyülésén Freund Tamás akadémikust választotta meg az MTA új elnökévé. A világhírü neurobiológus Lovász Lászlót követte a magyar tudományos köztestület élén, amelyet gróf Széchenyi István 1825-ben alapított. Az 1983-ban biológusdiplomát szerzett, Oxfordban többéves kutatómunkát folytató szakembert Vízi E. Szilveszter hívta haza 1990-ben az MTA Kísérleti Orvostudományi Kutatóintézet (KOKI) Morfológiai Osztálya élére. Freund Tamás 2002-től töltötte be a KOKI igazgatói posztját, amelyet a nemzetközi élvonalba tartozó agykutatási műhelyek között tartanak számon mind a mai napig. Az intézet erőssége a jó tudományszervezés mellett - hangzott el egy korábbi interjúban Oberfrank Ferenc részéről - a professzionális tudománymenedzsment, amely többek között Freund Tamás munkáját dicséri (URL1). Nincs annál felemelőbb érzés, mint amikor a tudomány kutatási eredményeivel, igazolt kísérleteivel a gyakorlati életet szolgálja. Ennek érdekében az új akadémiai elnök feltett szándéka, hogy jó kapcsolati rendszert építsen ki a minisztériumokkal, kormányzati intézményekkel, és nyisson a társadalom felé is. Hogy miként képzeli el ezt az építkezést, hogyan látja a Magyar Tudományos Akadémia elött álló kihívásokat - kérdeztük Freund Tamás elnök urat, akivel Hornyik Zsuzsanna beszélgetett.
\end{abstract}


Kulcsszavak: Magyar Tudományos Akadémia, interjú, köztestület

\begin{abstract}
The Hungarian Academy of Sciences (MTA) elected academic Tamás Freud for new president of MTA at its 193. Assembly with election of officials, on 7th July 2020. The world-famous neurobiologist followed László Lovász as president of the Hungarian scientific public body, which was founded by count István Széchenyi in 1825. After his graduation in 1983, he made researches in Oxford for several years, when he was invited back to Hungary by Szilveszter Vízi E. in 1990 to lead the Department Morphology of the Experimental Medical Scientific Research Institute (Hungarian abbreviation: KOKI) of the Academy of Sciences. Tamás Freund worked as president of KOKI from 2002 and made it to an internationally acknowledged centre of brain research. As Ferenc Oberfrank mentioned it in an earlier interview, the strength of the institute was beside excellent scientific organisation the professional science-management, thanks to the work of Tamás Freund -among others (URL1). It is esteeming to feel that science can help by its research results everyday life. To reach this aim, the new president of the academy intends to build out a good connection network with ministries, governmental institutions and simultaneously to open towards the society. How he imagines to build out this structure, and how he considers the challenges to the Hungarian Academy of Sciences? - about that was asked president Tamás Freund by Zsuzsanna Hornyik.
\end{abstract}

Keywords: Hungarian Academy of Sciences, interview, public body

\title{
Elnök Úr! Az MTA élére kerülve milyen intézkedéseket tart elsödlegesnek?
}

A programomban is azt tartottam a legfontosabbnak, hogy a Magyar Tudományos Akadémia visszanyerje régi presztízsét és megbecsültségét a társadalom és a kormányzat szemében is. Ez egy 18000 fős köztestület, amely lefedi az egész magyar tudományos kutatói szférát. Nincs egy alternatív akadémia, ez a nemzet ezt a kutatóközösséget volt képes kitermelni magából. Ha valaki ezt az akadémiát kárhoztatja, az gyakorlatilag a nemzet önbecsülését is károsítja. A jelenlegi kormányzatnak is fontos a nemzetiidentitás-tudat fejlődése. A kiemelkedő sportolók és müvészek mellett a magyar tudósokra is büszkék kell legyünk, és büszkék is lehetünk. A másik fontos dolog, hogy egyre intenzívebben kell küzdenünk az áltudományos eredmények terjedése ellen, hiszen a közösségi médián keresztül dől ránk a sok fals információ, és az átlagember sok esetben nem tudja megkülönböztetni a valódi tudományos kutatások eredmé- 
nyeit az áltudományok adataitól. Kire számíthatna másra az eligazodásban az utca embere, mint a tudósok közösségére. Ezért is fontos az MTA tekintélyének és hitelességének megörzése. Ezzel jól harmonizál az elnöki programom két legfontosabb pontja. Az egyik nyitás a kormányzat felé, a másik nyitás a társadalom felé.

Hogyan képzeli el a kormányzati szervekkel történö szoros együttmüködést, annak életben tartását?

A kormányzattal új alapokra kell helyezni a kommunikációt, ehhez azonban vissza kell nyerni a kölcsönös bizalmat. Az MTA egy nemzeti intézmény, nem lehet ellenzékben. A célom egy kommunikációs csatorna kiépítése az MTA és az egyes minisztériumok között. A tudományos tanácsadásnak ez a közvetlen és bizalmon alapuló volta az, amelyik kivédheti azokat a nyilvánosság előtt zajló vitákat, amely káros az MTA-nak, de egyúttal káros a kormányzatnak is. A tudomány és a politika összefogása abszolút nemzeti érdek. Ha bármelyik akadémiai osztály vagy szakbizottság bármelyik döntésben, törvénymódosításban, jogszabályjavaslatban hibát talál, akkor az előzetesen kiépített kommunikációs csatornán keresztül közvetlenül juttatjuk el a megfogalmazott, tudományos alapokon nyugvó véleményeket. Az esetek többségében arra számítunk, hogy eleve megrendelések fognak érkezni a különböző minisztériumok részéről, erre is fel kell készíteni őket, mert most az a jellemző, hogy nem igazán tudják, mit lehet kérdezni tőlünk. Példaként szoktam emlegetni a Belügyi Tudományos Tanácsot és az Egészségügyi Tudományos Tanácsot, amelyek közvetítőszerepet játszanak az MTA és a Belügyminisztérium, illetve az Emberi Erőforrások Minisztériuma felé. Ennek analógiájára képzelem el, hogy a többi minisztériumban is épüljön ki egy fogadó oldal, amely meg tudja fogalmazni a minisztériumokban felmerülő témák, törvényjavaslatok előkészítése során megfogalmazódó, tudományos megközelítést igénylő feladatok kapcsán a kérdéseket. Legyen valaki, aki ezeket le tudja fordítani a tudomány nyelvére és meg tudja fogalmazni az MTA részére. Az MTA-n belül pedig felállításra került a Köztestületi és Stratégiai Igazgatóság, amelynek igazgatója Oberfrank Ferenc, régi kollégám, akivel már a Kísérleti Orvostudományi Kutatóintézetben is együtt dolgoztunk. Volt egészségügyi államtitkár, OEP elnök, tudja miként müködik az államigazgatás, van tapasztalata ezen a téren, ismeri, hogyan funkcionál a politika. Ennek az igazgatóságnak az egyik feladata, hogy szervezze meg ezt a kommunikációs csatornahálózatot valamennyi minisztériumra kiterjesztve. Ennek a munkának a kezdeti fázisán lassan túljutunk, a miniszterek többségével már sikerült találkoznom, valamennyi tárca örül a megkeresésnek, és tárt karokkal várják az MTA közeledését. Hiszek benne, hogy a személyes 
kapcsolatfelvétel a kölcsönös bizalom kiépítésének egyik feltétele. Ez egy két irányú kommunikáció kíván lenni, egyrészt érkezhetnek megrendelések a döntéshozatalt segítő háttértanulmányok elkészítésére, másrészt az MTA részéről születhetnek figyelemfelhívások - például a világban új technológiák megjelenése, új gazdasági helyzet kialakulása kapcsán -, amelyeknek hatása lehet a kormányzásra. Elvárás a minisztériumok felé, hogy fogadókészség is legyen a részükről. Ez kellőképpen közvetlenné tudja tenni az MTA és a kormányzat kapcsolatát. A tudós közösséget pedig arra kell felkészíteni, hogy elöfordulhat az is, a kormány nem az általuk javasolt utat követi, hiszen neki nemcsak a tudományos szempontokat kell figyelembe vennie, hanem számos egyéb tényezőt. A tudományos tanácsadás úgy müködik, mint egy iránytü. Mindig mutatja merre van Észak, de ez nem azt jelenti, hogy mindig Észak felé kell menni. Egy politikus, aki megrendeli a tudományos háttértanulmányt, még ezen kívül figyelembe kell vegye a gazdasági, pénzügyi, külpolitikai, belpolitikai helyzetet, bármi egyéb faktort, amelyek akár mind másfelé mutathatnak. Ezeknek egy szintézise lesz a politikai döntés, amelyben ideális esetben alapvető szerepet kell játszania a tudományos szempontoknak. Jó, ha egy politikus tudja, merre mutat a tudomány, egy viszonyítási alap, amelyhez képest, ha eltérően dönt, meg tudja magyarázni, miért tette. Ezek után, ha a politikus mégsem a tudomány által javasolt utat választja, az már az ő felelőssége. A tudósok megtették a magukét.

Emlitette, hogy a társadalom felé is nyitni kíván. Ennek a folyamatnak melyek a mérföldkövei?

Programom szerint a nyitás a társadalom felé elsősorban a fiatalok megszólítását jelenti. Az idősebb generáció még mindig megbecsüléssel tekint a tudományra, a tudós testületekre. A fiatal generáció már fogékonyabb a közösségi médián keresztül ránk zúduló információáradatra, azt gyakran kritikátlanul fogadja, és hajlamos rá, hogy mindent elhiggyen. Öket könnyebb megvezetni és a tudomány ellen hangolni. Ezért azt gondolom, hogy ahhoz, hogy egy egészséges, tudománybarát generáció nőjön fel, a középiskolákat kell megcélozni tudományos ismeretterjesztéssel, a tudomány, a kutatómunka népszerüsítésével. Ezért találtam ki az MTA Középiskolák Alumni programot. Ennek beindítása érdekében a több mint 18000 köztestületi tagunknak kiküldünk egy levelet és egy online kérdőívet. A kérdőívben benne lesz, hogy a kitöltő az MTA mely osztályához, mely szakbizottságához tartozik, ez beazonosítja tudományos szakterületét. Megkérdezzük, melyik gimnáziumban érettségizett, hajlandó-e visszajárni oda időszakonként különböző előadásokat tartani, hajlandó-e más gimnáziumokba is elmenni, kutatóintézetekben vezetett túrát tartani vagy éppen ökológiai túrá- 
kat vállal-e, bölcsészként különböző foglalkozásokban számíthatunk-e rá. Ha a kérdőívek kitöltésre kerülnek, lesz egy olyan adatbázisunk, amelyik minden egyes köztestületi tagnál azonosítani fogja, hogy ő melyik gimnáziumban érettségizett és mi a szakterülete. Összeállítunk egy névsort a gimnáziumoknak arról, hogy köztestületi tagjaink közül kik érettségiztek náluk. Ezeket szakbizottságok szerint is osztályozni tudjuk. Ezután a gimnáziumokkal összefogva szeretnék tartani Alumni klubesteket. A saját gimnáziumommal már egyeztettem, velük fogjuk megcsinálni a pilot projektet, amelyet videóra is felveszünk. Én a veszprémi Lovassy László Gimnáziumba jártam, amelyik jelenleg az ország egyik legjobb gimnáziuma. Az igazgatóval megbeszéltem, hogy négy harmincperces blokk lesz, egy élettudós, egy élettelen természettudós, egy bölcsész/társadalomtudós és egy mérnök/informatikus bevonásával. Ebben a négyszer harminc perces blokkban tizenöt percet beszél az elöadó, tizenöt percben lehet kérdezni, majd a végén kötetlen beszélgetés lesz az előadók és fiatalok között. Elsősorban nem neves akadémikusokat szeretnék visszavinni a középiskolákba, hanem azokat, akik épphogy megszerezték a doktori fokozatukat, hiszen ök korban is közelebb vannak a diákokhoz, jobban értik a nyelvüket. Ők még nem tartoznak az elérhetetlennek tünő tudós nagyságokhoz. Nagy nemzetközi sikereket még nem értek el, de már azok küszöbén állnak, tudnak mesélni a kutatás szépségéről, a felfedezés öröméről, hogy milyen jó dolog tudósnak lenni, mitől lesz hiteles egy tudós, mitől lesz hiteles egy kutatás, egy eredmény, milyen adatokban lehet bízni, miben nem, s mindezt annak érdekében, hogy a diákok egy kicsit tájékozódni tudjanak a rájuk zúduló információözönben. Nem kell mindenkinek kutatóvá válni, bőven elég, ha megtanulják tisztelni a tudományt és hitelesnek fogják tekinteni azt, miután meghallgattak jó néhány előadást a legváltozatosabb kutatási területekről. Bízom benne, hogy a gimnáziumok többsége vállalni fogja, hogy minden hónapban egy délutánt erre áldozzon. A Lovassy László Gimnázium igazgatója úgy látja, hogy a havi rendszerességgel ismétlődő program részükről megvalósítható. Az MTA, köszönhetően az adatbázisnak, a legváltozatosabb területekről tudja biztosítani az előadókat. Lehetnek külön megrendelések is, akár laboratórium látogatások egy biológia, kémia vagy fizika szakkör diákjainak az Alumni releváns előadóihoz irányítva. Ki kell épüljön az Alumni klubok hálózata az MTA, másik oldalon pedig az érdeklődő diákok csoportja részéről. Korábban a köztestület tagjai nem voltak bevonva semmilyen összakadémiai feladatba. A saját doktoranduszaim kérdeztek régebben, amikor bíztattam őket, hogy a $\mathrm{PhD}$ megvédése után jogosultként lépjenek be az MTA köztestületébe, hogy minek. Most remélem megtudják és átérzik, hogy a társadalomnak mi haszna lesz belöle. Óriási jelentőségü feladat fog rájuk hárulni ezzel az Alumni programmal, és a szakbizottságok újszerü felállításával is. 
Vajon mennyire ismerik az emberek az MTA-t, annak müködését, tevékenységi körét?

Az átlagember nem tudja, hogy az MTA egy 18000 kutatóból álló köztestület, azt meg pláne nem tudja, hogy mi köze van ennek a többezer kutatónak ahhoz, hogy kiből lesz akadémikus. Az akadémikusok köre szavazza meg, kit választanak be maguk közé, viszont azt, hogy kikből választhatnak - csak a nagydoktorokból választhatnak -, hogy kiből lesz akadémiai doktor, közvetve ettől a 18000 fös köztestülettől függ, hiszen ők választják meg a szakbizottságokat. Van tizenegy osztály, ebben összesen nyolcvanhat szakbizottság. Vegyük például a biológiai osztályt. Itt van ökológiai, neurobiológiai, diverzitásbiológiai, molekuláris biológiai, genetikai és sejtbiológiai bizottság. Viszonylag jól körülhatároltan megvan minden szakterületeknek a maga bizottsága, amelynek tagjait a köztestület választja. A köztestületi tagok között például van néhányszáz neurobiológus, akik maguk közül választják meg a huszonnégy fős neurobiológiai szakbizottságot. Ennek tagja automatikusan minden akadémikus - jelenleg hat fö -, de ehhez még tizennyolcat a köztestület választ, és majd ez a szakbizottság fogja a nagydoktori eljárásokat elbírálni, a habitusvizsgálatokat lefolytatni, eldönteni, hogy eljárásra bocsátható-e a jelölt. Ez a bizottság nevezi meg az opponenseket, tehát ez a 18000 fös köztestület határozza meg indirekt módon, hogy kiböl lehet akadémiai doktor. Az Alumni program mellett még sok pluszfeladat fog hárulni ezekre a szakbizottságokra. Eddig egyetlen elnök sem szólította meg közvetlenül a köztestületi tagságot. Senki nem hívta fel a figyelmüket arra, hogy feladatuk van, felelősséggel tartoznak a nemzet felé, az ország jövőjéért, hiszen ők ennek az országnak a tudósai és egy nemzeti intézmény tagjai. Ez a felelősség konkrét tevékenységgel jár. A kutatóhálózat kiszervezése kapcsán jutott eszembe, hogy lehetőségeink emiatt nem szükültek be, hanem tulajdonképpen kitágultak, hiszen a kutatóhálózat 3000 kutatója helyett most 18000 fö vehet részt az MTA közfeladatainak ellátásában. Nemcsak a kutatóhálózat kutatóira, mint köztestületi tagokra támaszkodhatunk a jövőben, hanem az összes egyetemen és ipari kutatóhelyen dolgozó tagra is. Fontos feladata lesz a szakbizottságoknak a jövőben a kutatóhelyek minősítése is. Eddig csak a tudósokat minősítették a tudományok doktora cím adományozásával. Ezt a minősítési eljárást szeretném kiterjeszteni az egyénekről a kutatóhelyekre is. Minden egyes szakbizottság a hozzátartozó kutatóhelyeket fel fogja mérni, készít egy katasztert arra vonatkozóan, hogy hol, melyik egyetemen, milyen ipari vállalatnál vagy éppen az Eötvös Kutatóhálózatban milyen fajta kutatási kapacitás van. Ezeket rendszeresen látogatja majd és minősíti. A tudomány doktora címhez hasonló minősítési rendszert fogunk kidolgozni, ami adaptálható a kutatóhelyekre. Nyilván bizonyos dolgokban különbözni fog az egyénekre alkalmazott bírálattól, de a tudománymetriai 
adatoktól kezdve tervek, eredmények, szabadalmak, ipari hasznosulási mutatók, $\mathrm{PhD}$ programban való részvétel, oktatási feladatok felmérése, értékelése megvalósítható, és ezek alapján adományozható az MTA kiváló kutatóhely cím. Ezt elnyerni akkor akarja egy kutatóhely, egy tanszék, ha az jár valamivel. Jelenleg ennek kialakításán is dolgozunk. Ha például az MTA és más pályáztató fórum feltételként jelöli meg a cím meglétét, vagy ha sikerül a rektorokkal megegyezni arról, hogy a $\mathrm{PhD}$ helyek elosztásakor élvezzenek előnyt azok, akik birtokosai ennek a címnek, azzal már sokat tettünk az ügy érdekében. Az MTA, mint minőségbiztosító és teljesítményértékelő intézmény az egyetlen az egész országban amelyik képes arra, hogy a kutatók mellett a kutatóhelyeket is minősítse.

\section{Milyen konkrét tapasztalatai vannak a Belügyi Tudományos Tanáccsal történö együttmüködéssel kapcsolatban?}

A Belügyi Tudományos Tanács által korábban szervezett nemzetközi konferencia alkalmával előzetes véleményt kértek tőlem annak programjáról, előadás megtartására is felkértek, amely később egy tanulmánykötetben is megjelentetésre került a többi elhangzott előadással együtt. Lenyügözött az igényesség és a tudomány megbecsülése, valamint a belügyhöz kapcsolódó tudományterületek képviselőinek ily módon történő igénybevétele. Jó, hogy van a tudománynyal való kommunikációnak megtestesítője, hidat képezve a minisztérium és az MTA között, ezáltal folyamatos kapcsolattartásra van lehetőség.

Miként tudják segíteni elképzelésének megvalósulását a hazai tudományos folyóiratok, köztük a Belügyi Szemle?

Biztos vagyok abban, hogy minden platform, amely ezeknek az együttmüködéseknek, döntések tudományos előkészítésének népszerüsítését szolgálja az jó és hasznos a társadalom számára. A minisztériumi, tárcaszintü döntések, törvények előkészítése is hitelesebbé válik a társadalom szemében, ha tudják, hogy e mögött ott áll a tudományosság. A hazai tudományosság letéteményese pedig az MTA. A minisztériumok egész müködését eredményesebbé teheti a tudomány eredményeire való támaszkodás. Ennek a népszerüsítése nyilván a folyóiratok, így a Belügyi Szemlének is a feladata.

\section{Hogyan látja a magyar tudósok helyzetét a világban?}

Jó néhány tudományterület van, ahol ott vagyunk az élvonalban, ezeket a pozícióinkat hosszú évtizedek kemény munkájával lehetett elérni. Például a neurobiológiát, agykutatást illetően abszolút az élmezőnyhöz tartozunk. Amikor az intézetünket (KOKI) értékelte az idegtudományi világszövetség, azt írták a honlapjukon, hogy a mi intézetünk és rajta keresztül a magyar agykutatás föszerepet 
játszik a világ idegtudományának központi színpadán. Ezt támasztja alá, hogy hányan nyertek el ERC (Európai Kutatási Tanács - European Research Council) pályázatot, amely ma Európa legnagyobb presztízsü kutatási pályázata. Az idegtudomány területén már 15-16 ilyen pályázatot nyertünk el, ebből a KOKI 10-et. Matematikusaink a Rényi Matematikai Intézetben nyolc ERC pályázatnál járnak, méltán világhírủek. A múlt században atomfizikusaink, akik a korábbi történelmi események következtében külföldön folytatták tudományos munkásságukat, jelentették a világ élvonalát. A ma itt élő tudósok között is sokan vannak, akiknek köszönhetően hazánk ott van a világ tudományosságának térképén. Ha megkapják a kellő elismerést és megbecsülést mind a kormányzattól, mind a társadalomtól, akkor maradni is fognak. Kell egy életpályamodell, amely biztosítja öket arról, hogy érdemes itthon maradni, hiszen ne felejtsük el, egyébként elárasztják őket a külföldi ajánlatok.

\section{Mit üzent a magyar tudomány ünnepe alkalmából?}

A tudomány hónapja egyfajta üzenet, a társadalom megszólítása. Ilyenkor nyitják meg kapuikat az intézetek, kutatómühelyek, egyetemek. A tudomány hónapja rendezvénysorozatnak célja kivinni a tudományt az emberek közé, azért, hogy ne úgy tekintsenek a tudósvilágra, mint akik elefántcsonttoronyba zárkóztak és valami érthetetlen, öncélú dolgon törik a fejüket. Éljék át, mit jelent a tudomány művelése, a felfedezés öröme. Annak érdekében pedig, hogy erre ne csak ilyenkor kerüljön sor, jön létre az Alumni program. A társadalom széles rétegei felé megfogalmazott üzenetem, hogy bízzanak a tudósokban, bízzanak a tudományban, hiszen csak rájuk számíthatnak a mai áltudományokkal terhelt világban, és felfedezéseikkel, tudományos kutatómunkájukkal - közvetlenül vagy közvetve a közjót szolgálják. A tudósok figyelmét pedig arra szeretném felhívni, nagy felelősségük van abban, hogy segítsék az MTA-t ennek a küldetésnek a teljesítésében.

\section{Az interjúban található online hivatkozások}

URL1: Elnökjelölti portrék - Freund Tamás. https://mta.hu/mta_hirei/elnokjelolti-portrek-freund-tamas-110416

\section{A cikk APA szabály szerinti hivatkozása}

Hornyik Zs. (2020): Legyen a tudomány az iránytü mindenki számára! Interjú Freund Tamással, a Magyar Tudományos Akadémia elnökével. Belügyi Szemle, 69(1), 157-164. https://doi. org/10.38146/BSZ.2021.1.9 